\title{
FAKTOR-FAKTOR PENGHAMBAT BELAJAR RENANG PADA SISWA KELAS X DI SMA NEGERI 1 MUARA ENIM
}

\author{
Amalia Barikah \\ E-mail: amaliabarikah29@gmail.com \\ Universitas Islam Kalimantan MAB Banjarmasin
}

\begin{abstract}
This study was aimed to determine theinhibiting factors of swimming exercise of eighth grade students at State Senior High School 1 Muara enim. This study was descriptive research with survey methods. The data collection technique used was questioners. The questioners were determining the internal and external factors including 29 items. The population was Ten grade students at State senior High School 1 Muara enimtotaling of 130 students. Data analyses technique used was descriptive analyses. The results indicatedthat theinhibiting factors of swimming exercise of Ten grade students at State Senior High School 1 Muara enimwere 9 students $(6,9 \%)$ had very high category, 22 students $(16,9 \%)$ had high category, 56 students $(43,1 \%)$ had medium category, 40 students $(30,8 \%)$ had low category and 3 students $(2,3 \%)$ had very low category.
\end{abstract}

Keywords: inhibiting factors, swimming exercise, students 


\section{PENDAHULUAN}

Aktivitas belajar setiap individu berbeda-beda dan tidak selamanya berjalan dengan lancar. Ada kalanya seseorang mengalami hambatan di dalam belajar sehingga materi ajar yang ia terima tidak dapat diserap dengan baik dan hasil belajarnya menjadi tidak memuaskan. Menurut Slameto (2010: 2), "Belajar adalah suatu proses usaha yang dilakukan seseorang untuk memperoleh suatu perubahan tingkah laku yang baru secara keseluruhan, sebagai hasil pengalamannya sendiri dalam interaksi dengan lingkungannya". Sedangkan menurut Sugihartono dkk (2009: 74), belajar merupakan suatu proses perubahan tingkah laku sebagai hasil interaksi individu dengan lingkungannya dalam memenuhi kebutuhan hidupnya. Hambatanhambatan inilah yang nantinya akan mengganggu proses belajar yang dialami oleh seseorang. Slameto (2010: 54-72) menjelaskan bahwa faktor-faktor yang mempengaruhi belajar adalah faktor internal (jasmaniah, psikologis dan kelelahan) dan eksternal (keluarga, sekolah dan masyarakat).

Faktor fisiologis dapat dibedakan menjadi dua macam, yaitu keadaan tonus jasmani pada umumnya dan keadaan fungsi panca indera. Keadaan jasmani tonus jasmani melatar belakangi aktivitas belajar. Keadaan jasmani yang akan membuat badan tidak mudah lelah, begitu pula sebaliknya. Oleh karena itu nutrisi harus cukup karena kekurangan kadar makanan ini akan mengakibatkan keadaan jasmani menjadi kurang baik akibatnya badan menjadi lesu, cepat mengantuk dan lelah. Selain itu juga penyakit yang diderita dapat mengganggu belajar, misalnya adalah pilek, sakit gigi, batuk dan sebagainya. Penyakit ini sering kali diabaikan namun dalam kenyataannya dapat mengganggu belajar. Selain keadaan jasmani, baik buruknya panca indera juga menjadi syarat berlangsungnya belajar. Panca indera yang erat kaitannya dengan proses belajar yaitu mata dan telinga. kondisi organ tubuh yang lemah seperti pusing-pusing dapat mengganggu belajar siswa. Nutrisi yang cukup, istirahat dan olahraga ringan dan berkesinambungan juga penting bagi siswa.

Menurut Sugihartono dkk (2009: 1), psikologi berasal dari kata psyche dan logos. Psyche berarti jiwa dan logos berarti ilmu. Secara harafiah psikologi dapat diartikan sebagai ilmu jiwa. Jadi psikologis dapat diartikan segala sesuatu yang berhubungan dengan kejiwaan seseorang. 
Menurut Slameto (2010: 60-64), siswa yang belajar akan menerima pengaruh dari keluarga berupa cara orang tua mendidik, relasi antar anggota keluarga, suasana rumah tangga dan keadaan ekonomi keluarga. Misalnya orang tua tidak memperhatikan pendidikan anaknya, tidak memperhatikan kebutuhan anak, tidak mengatur waktu belajar, dan tidak menyediakan/melengkapi alat belajar. Selain itu juga hubungan antar anggota keluarga seperti orang tua dengan anak, atau anggota keluarga yang lain turut berpengaruh, suasana rumah yang sering ribut, cekcok, semrawut dan tidak memberi ketenangan juga merupakan faktor penghambat dari keluarga. Selain itu juga keadaan ekonomi keluarga, misalnya anak yang tinggal pada keluarga yang miskin tidak akan terpenuhi kebutuhan pokoknya seperti makan, perlingdungan kesehatan, pakaian, fasilitas belajar, alat tulis dan sebagainya.

Selanjutnya Slameto (2010: 70-71), menjelaskan bahwa masyarakat sebagai faktor eksternal dapat mempengaruhi belajar siswa, jika siswa mengikuti organisasi, kegiatan sosial, keagamaan, dan tidak dapat mengatur waktu belajarnya maka kegiatan belajar dapat terganggu. Selain itu juga keberadaan mass media juga dapat berpengaruh terhadap belajar siswa. Yang termasuk ke dalam mass media adalah bioskop, radio, tv, surat kabar, majalah, buku-buku, komik dan lain-lain. Media yang baik akan memberi pengaruh yang baik, begitu pula sebaliknya. Teman bergaul siswa juga berpengaruh terhadap belajar, teman yang baik akan berdampak baik dan sebaliknya. Teman yang tidak baik misalnya suka begadang, keluyuran, pecandu rokok,minum-minuman dan sebagainya.

Menurut Supriyadi (2013:11),guru merupakan pendidik profesional dengan tugas utama mendidik, mengajar, membimbing, mengarahkan, melatih, menilai, dan mengevaluasi peserta didik pada jalur pendidikan formal. Jadi, dalam pelaksanaan pembelajaran di sekolah guru memiliki tugas seperti disebutkan di atas.

Sebagai seorang pendidik, guru harus memenuhi beberapa syarat khusus. Untuk mengajar ia dibekali dengan berbagai ilmu keguruan sebagai dasar, disertai pula seperangkat latihan keterampilan keguruan, dan pada kondisi itu pula ia belajar memersonalisasikan beberapa sikap keguruan yang diperlukan.(Sardiman A.M., 2010: 138)

Menurut Kamus Besar Bahasa Indonesia (2002: 999) yang dikutip oleh Bambang Sarjono (2010: 16) dalam skripsinya, "Sarana adalah segala seuatu yang dapat 
sebagai alat dalam mencapai tujuan dan maksud", sedangkan 'prasarana adalah segala sesuatu yang merupakan penunjang utama suatu proses."

Pada penelitian ini akan dibahas tentang faktor penghambat belajar renang.Dalam Kamus Umum Bahasa Indonesia, disebutkan bahwa hambatan berasal dari kata dasar hambat yang berarti menahan, menghalangi, merintangi. Sedangkan hambatan sendiri merupakan halangan, rintangan. Hambatan adalah sesuatu yang bersifat negatif yang menahan laju suatu program sehingga program tersebut tidak sesuai dengan harapan. Hambatan dapat terjadi dimana saja, termasuk dalam dunia pendidikan. Hambatan dalam dunia pendidikan dapat berarti segala sesuatu yang menghalangi proses belajar mengajar di sekolah sehingga hasil yang diharapkan tidak sesuai dengan harapan. Hasil ini sangat erat hubungannya dengan siswa sebagai subjek dalam kegiatan belajar mengajar itu sendiri..

Renang adalah salah satu bagian dalam aktivitas air yang tidak diajarkan di semua sekolah. Hal ini dikarenakan keterbatasan sarana prasarana yang dimiliki sekolah untuk pembelajaran renang begitu terbatas. Sekolah yang melaksanakan pembelajaran renang yaitu SMA Negeri 1 Muara Enim. SMA Negeri 1 Muara Enim melaksanakan pembelajaran renang sebanyak tiga kali dalam satu semester untuk setiap kelas. Dalam hal ini peneliti fokus pada kelas $\mathrm{X}$, hal ini dikarenakan pada kelas X siswa telah mendapatkan banyak pengalaman dalam pembelajaran renang sebelumnya serta masih memiliki kesempatan yang cukup untuk memperbaiki hasil belajarnya di kelas berikutnya.

Dalam memberikan materi ajar, SMA Negeri 1 Muara Enim masih menggunakan Kurikulum KTSP sehingga materi ajar renang yang diberikan kepada siswa kelas Xberpedoman pada Standar Kompetensi dan Kompetensi Dasar yang tercantum di dalam Kurikulum KTSP.

Berdasarkan interview yang telah dilakukan dengan Guru Pendidikan Jasmani, Olahraga dan Kesehatan di SMA Negeri 1 Muara Enim, pihak sekolah tidak menanggung biaya masuk kolam renang biaya untuk transportasi menuju kolam renang, oleh karena itu siswa membeli tiket kolam renang dengan biaya pribadi dan menuju kolam renang dengan menaiki sepeda.Selain itu jumlah pelampung yang tersedia juga sedikit dan tidak mencukupi jumlah siswa sehingga siswa harus bergantian untuk menggunakannya. Siswa tidak pernah menggunakan kacamata 
renang maupun alat pelindung rambut saat belajar renang. Saat belajar renang siswa juga tidak menggunakan pakaian renang melainkan menggunakan pakaian olahraga. Berdasarkan hasil interview dengan sebagian siswa kelas Xdi SMA Negeri 1 Muara Enim diketahui bahwa banyak siswa masih mengalami kesulitan dalam belajar renang bahkan banyak juga yang tidak bisa berenang. Sebagian dari mereka mengakui bahwa mereka kurang percaya diri dan malu saat belajar renang, selain itu juga siswa sulit mengkordinasikan antara gerakan lengan, tungkai dan pernafasan. Tidak dipungkiri, faktor-faktor tersebut hanya sebagian kecil dari faktor-faktor penghambat belajar yang ada.

\section{TINJAUAN PUSTAKA}

Menurut Miyanto (2008: 11-15), aktivitas berenang memerlukan beberapa sarana yaitu:

a) Kolam renang

Dalam berenang, sebaiknya menggunakan kedalaman yang aman bagi anak. Jika anak belum bisa beranang, maka menggunakan kolam khusus, namun jika sudah mahir maka menggunakan kolam yang dalam.

b) Pakaian renang

Pakaian renang membuat nyaman selama beraktivitas di dalam air. Disarankan untuk memilik pakaian renang yang nyaman dipakai.

c) Pelindung rambut

Saat berenang tidak harus menggunakan pelindung rambut. Namun jika kegiatan berenang dilakukan di tempat terbuka dan terkena sinar matahari langsung maka pelinsung rambut perlu untuk dimiliki.

d) Kacamata

Kacamata renang juga perlu untuk digunakan saat berenang. Alat ini mampu melindungi indera penglihatan agar tidak perih ata merah.

e) Pelampung

Pelampung merupakan alat pengaman dalam hal-hal yang berhubungan dengan air, termasuk berenang. Alat ini mampu menahan tubuh sehingga tidak tenggelam. Alat ini cocok digunakan oleh orang yang belum mahir dalam berenang. 
Menurut Ermat Suryatna dan Adang Suherman (2004: 104-107), teknik gaya dada yaitu:

\section{a. Posisi Tubuh}

Posisi tubuh lurus mendatar permukaan air, kepala diangkat sedikit lebih tinggi dari bahu, kedua lengan dan tangan lurus telapak tangan menghadap ke bawah dan tungkai diluruskan secara relax di bawah permukaan air dengan telapak menghadap ke atas.

\section{b. Gerakan Lengan}

Pergelangan tangan diputar sehingga jari tangan menghadap ke bawah luar. Dahu diangkat saat melakukan tarikan tangan. Tenaga dorongan dihasilkan oleh telapak tangan. Tarikan tangan tidak melebihi batas bahu dan dilakukan hanya setengan dari gerakan lengan. Selanjutnya tangan ditarik ke bawah dagu untuk recovery, lalu masukkan muka ke dalam air, dorong dan luncurkan kedua lengan ke depan.

\section{c. Gerakan Tungkai}

Diawali dengan membengkokan tangan dan lutut, dan sendi untuk menarik kaki dekat pantat dan paha. Pada saat telah mendekati paha, kaki diputar keluar hingga ujung jari kaki menghadap ke luar. Luruskan kedua lutut kea rah luar belakang dan rapatkan lurus kembali hingga horizontal pada permukaan air.

\section{d. Gerakan Ambil Nafas}

Pada saat lengan melakukan gerak menarik dari depan ke bawah dagu, maka dagu diangkat untuk melakukan pengambilan nafas. Pengambilan nafas dilakukan setengah detik lalu masukkan muka kembali saat lengan melakukan gerakan recovery.

\section{e. Gerakan Koordinasi Lengan, Tungkai dan Nafas}

Mulailah gerakan menarik lengan dan angkat dagu ke atas untuk mengambil nafas, sementara itu tekuk lutut untuk melakukan gerakan recovery pada kaki. Pada saat tangan melakukan rotasi di bawah bagu maka kaki melakukan dorongan ke arah luar belakang. Masukkan muka ke dalam air bersamaan lurusnya lengan dan kaki untuk meluncur.

Siswa kelas Xdi SMA Negeri 1 Muara Enim yang menjadi posisi sentral dari pembelajaran renang di sekolah tentu saja memiliki asumsi masing-masing tentang 
faktor yang menghambat mereka dalam belajar renang. Dari hasil interview dengan guru di SMA Negeri 1 Muara Enim, penelitian tentang faktor-faktor penghambat belajar renang pada siswa kelas Xdi SMA Negeri 1 Muara Enim belum pernah dilakukan. Oleh karena itu untuk mengungkap berapa besarnya faktor-faktor penghambat belajar renang pada siswa kelas Xdi SMA Negeri 1 Muara Enim tersebut maka peneliti merasa penelitian ini perlu untuk dilakukan.

\section{METODOLOGI}

Penelitian ini menggunakan metode penelitian deskriptif. Penelitian ini dilaksanakan di SMA Negeri 1 Muara Enim yang terletak di KecamatanMuara EnimKabupatenMuara Enim.

Variabel dalam penelitian ini yaitu faktor-faktor penghambat belajar renang pada siswa kelas Xdi SMA Negeri 1 Muara Enim, artinya interpretasi siswa kelas Xdi SMA Negeri 1 Muara Enimterhadap semua yang dapat menjadi penghambat belajar renang pada siswa kelas Xdi SMA Negeri 1 Muara Enim.Faktor-faktor penghambat belajar renang pada siswa kelas Xdi SMA Negeri 1 Muara Enim dapat diukur melalui faktor-faktor yang dapat menghambat belajar renang yaitu faktor internal dan faktor eksternal. Pada faktor internal dapat dilihat indikator fisiologis dan psikologis dan pada faktor eksternal dilihat melalui indikator lingkungan sosial, guru dan sarana prasarana.

Populasi yang digunakan dalam penelitian ini adalah siswa kelas Xdi SMA Negeri 1 Muara Enim berjumlah 130 siswa yang diambil dengan teknik Sampling Jenuh.

Teknik analisis data yang digunakan dalam penelitian ini adalah statistik deskriptif kuantitatif dengan menggunakan persentase.

Persentase faktor-faktor penghambat belajar renang pada siswa kelas X di SMA Negeri 1 Muara Enim dapat dihitung dengan menggunakan rumus:

$$
\mathrm{P}=\mathrm{F} / \mathrm{N} \times 100 \%
$$

Keterangan:

P : Angka Persentase

F : Frekuensi yang sedang dicari

persentasenya 
Volume 4 Nomor 2, Oktober 2018

$\mathrm{N} \quad$ : Number of cases (Jumlah

frekuensi/banyaknya individu)

Sumber: Sugiyono (2010:89)

\section{PEMBAHASAN}

Distribusi frekuensi faktor-faktor penghambat belajar renang pada siswa kelas Xdi SMA Negeri 1 Muara Enimdisajikan dalam tabel berikut:

Tabel 1. Distribusi Frekuensi Hambatan Belajar Renang pada Siswa

\begin{tabular}{|c|c|c|c|c|}
\hline No. & Kategori & Interval & $\mathrm{F}$ & Persen \\
\hline 1 & Sangat Tinggi & $79,6798<X$ & 9 & $6,9 \%$ \\
\hline 2 & Tinggi & $69,3665<X \leq 79,6798$ & 22 & $16,9 \%$ \\
\hline 3 & Sedang & $59,0535<X \leq 69,3665$ & 56 & $43,1 \%$ \\
\hline 4 & Rendah & $48,7405<X \leq 59,0535$ & 40 & $30,8 \%$ \\
\hline 5 & Sangat Rendah & $X \leq 48,7405$ & 3 & $2,3 \%$ \\
\hline \multicolumn{3}{|c|}{ Jumlah } & 130 & $100,0 \%$ \\
\hline
\end{tabular}

Berdasarkan tabel 1, maka dapat dilihat bahwa sebanyak 56 siswa $(43,1 \%)$ menyatakan hambatan dalam belajar renang masuk ke dalam kategori hambatan "sedang", disusul 40 siswa (30,8\%) dalam kategori hambatan "rendah", 22 siswa $(16,9 \%)$ menyatakan kedalam kategori hambatan "tinggi", 9 siswa $(6,9 \%)$ menyatakan ke dalam kategori hambatan "sangat tinggi" dan 3 siswa (2,3\%) menyatakan dalam kategori "sangat rendah". Dari persentase tersebut dapat disimpulkan bahwa faktor-faktor yang menghambat belajar renang siswa kelas Xdi SMA Negeri 1 Muara Enim masuk ke dalam kategori hambatan "sedang".

Faktor penghambat belajar renang siswa kelas Xdi SMA Negeri 1 Muara Enim terdiri dari 2 Faktor yang terbagi menjadi 5 indikator yang perbandingannya disajikan dalam tabel berikut:

Tabel 2. Hasil Perbandingan Kategori Hambatan Belajar Renang padakelas XTiap Faktor dan Indikator

\begin{tabular}{|l|l|l|l|l|}
\hline Variabel & \multicolumn{1}{|c|}{ Faktor } & Kategori & \multicolumn{1}{|c|}{ Indikator } & Kategori \\
\hline Faktor- & 1. Internal & Sedang & 1. Fisiologis & Rendah \\
\cline { 4 - 5 } faktor & & & 2. Psikologis & Sedang \\
\cline { 3 - 5 } penghambat & 2. Eksternal & Sedang & 3. Lingk.Sosial & Sedang \\
\cline { 4 - 5 } Belajar & & & 4. Guru & Sedang \\
\cline { 4 - 5 } Renang & & & 5.Sarana & Rendah \\
pada Siswa & & & Prasarana & \\
Kelas X di & & & & \\
SMA N 1 & & & & \\
Muara Enim & & & & \\
\hline
\end{tabular}


Dari tabel tersebut maka faktor-faktor penghambat belajar renang pada siswa kelas Xdi SMA Negeri 1 Muara Enim akan dijabarkan dari masing-masing faktor dan indikatornya.

\section{Faktor Internal}

Distribusi frekuensifaktor internal disajikan dalam tabel berikut:

Tabel 3. Distribusi Frekuensi Hambatan Belajar Renang Faktor Internal.

\begin{tabular}{|c|c|c|c|c|}
\hline No. & Kategori & Interval & $\mathrm{F}$ & Persen \\
\hline 1 & Sangat Tinggi & $35,005<X$ & 9 & $6,9 \%$ \\
\hline 2 & Tinggi & $30,135<X \leq 35,005$ & 21 & $16,2 \%$ \\
\hline 3 & Sedang & $25,265<X \leq 30,135$ & 54 & $41,5 \%$ \\
\hline 4 & Rendah & $20,395<X \leq 25,265$ & 40 & $30,8 \%$ \\
\hline 5 & Sangat Rendah & $X \leq 20,395$ & 6 & $4,6 \%$ \\
\hline \multicolumn{3}{|c|}{ Jumlah } & 130 & $100,0 \%$ \\
\hline
\end{tabular}

Berdasarkan tabel di atas maka diketahui bahwa 54 siswa (41,5\%) menyatakan ke dalam kategori "sedang”, disusul 40 siswa (30,8\%) menyatakan kedalam kategori "rendah", 21 siswa (16,2\%) ke dalam kategori "tinggi”, 9 siswa (6,9\%) menyatakan ke dalam kategori "sangat tinggi", dan 6 siswa (4,6\%) menyatakan ke dalam kategori "sangat rendah".Dari persentase tersebut dapat disimpulkan bahwa faktor internal termasuk ke dalam kategori hambatan "sedang".

Dari faktor interal penghambat belajar renang pada siswa kelas Xdi SMA Negeri 1 Muara Enim terdiri dari dua indikator yaitu fisiologis dan psikologis. Penjabarann masing-masing indikator yaitu:

\section{Indikator Fisiologis}

Distribusi frekuensi indikator fisiologisdisajikan dalam tabel berikut ini.

Tabel 4. Distribusi Frekuensi Hambatan Belajar Renang Indikator Fisiologis.

\begin{tabular}{|c|c|c|c|c|}
\hline No. & Kategori & Interval & $\mathrm{F}$ & Persen \\
\hline 1 & Sangat Tinggi & $13,626<X$ & 11 & $8,5 \%$ \\
\hline 2 & Tinggi & $11,342<\mathrm{X} \leq 13,626$ & 22 & $16,9 \%$ \\
\hline 3 & Sedang & $9,058<X \leq 11,342$ & 43 & $33,1 \%$ \\
\hline 4 & Rendah & $6,774<\mathrm{X} \leq 9,058$ & 49 & $37,7 \%$ \\
\hline 5 & Sangat Rendah & $X \leq 6,774$ & 5 & $3,8 \%$ \\
\hline \multicolumn{3}{|c|}{ Jumlah } & 130 & $100,0 \%$ \\
\hline
\end{tabular}


bahwa 49 siswa $(37,7 \%)$ menyatakan hambatan indikator fisiologis ke dalam kategori "rendah", disusul 43 siswa $(33,1 \%)$ menyatakan kedalam kategori “sedang”, 22 siswa (16,9\%) menyatakan ke dalam kategori "tinggi”, 11 siswa $(8,5 \%)$ menyatakan ke dalam kategori "sangat tinggi", dan 5 siswa $(3,8 \%)$ menyatakan ke dalam kategori "sangat rendah". Dari persentase tersebut dapat disimpulkan bahwa faktor internal indikator fisiologis termasuk ke dalam kategori hambatan "rendah".

Dari hasil penelitian disimpulkan bahwa indikator fisiologis termasuk ke dalam kategori hambatan "rendah". Hambatan yang rendah ini dikarenakan siswa kelas Xdi SMA Negeri 1 Muara Enim yang kebanyakan berasal dari pedesaan memiliki perkembangan motorik yang baik, selain itu juga sudah terbiasa dengan aktivitasaktivitas yang berhubungan dengan gerak. Oleh karena itu kondisi fisik siswa kelas Xdi SMA Negeri 1 Muara Enim cukup baik untuk menunjang aktivitas pembelajaran khususnya renang.

\section{Indikator Psikologis}

Distribusi frekuensi hambatan belajar renangindikator psikologis disajikan dalam tabel berikut ini.

Tabel 5. Distribusi Frekuensi Hambatan Belajar Renang Indikator Psikologis.

\begin{tabular}{|c|c|c|c|c|}
\hline No. & Kategori & Interval & $\mathrm{F}$ & Persen \\
\hline 1 & Sangat Tinggi & $22,657<X$ & 14 & $10,8 \%$ \\
\hline 2 & Tinggi & $19,219<X \leq 22,657$ & 12 & $9,2 \%$ \\
\hline 3 & Sedang & $15,781<\mathrm{X} \leq 19,219$ & 69 & $53,1 \%$ \\
\hline 4 & Rendah & $12,343<X \leq 15,781$ & 31 & $23,8 \%$ \\
\hline 5 & Sangat Rendah & $X \leq 12,343$ & 4 & $3,1 \%$ \\
\hline \multicolumn{3}{|c|}{ Jumlah } & 130 & $100,0 \%$ \\
\hline
\end{tabular}

Berdasarkan tabel di atas maka diketahui sebanyak 69 siswa $(53,1 \%)$ menyatakan hambatan belajar renang indikator psikologis ke dalam kategori "sedang", 31 siswa $(23,8 \%)$ menyatakan ke dalam kategori "rendah", 14 siswa (10,8\%) menyatakan ke dalam kategori "sangat tinggi", 12 siswa (9,2\%) menyatakan ke dalam kategori "tinggi", dan 4 siswa $(3,1 \%)$ menyatakan ke dalam kategori "sangat rendah". Dari persentase tersebut dapat disimpulkan bahwa faktor internal indikator psikologis termasuk ke dalam kategori hambatan "sedang".

Dari hasil penelitian disimpulkan bahwa indikator psikologis termasuk ke dalam kategori hambatan "sedang". Hal ini dikarenakan sebagian besar siswa sudah terbiasa 
dengan kegiatan di air sehingga mereka merasa hambatan dari faktor psikologis cenderung sedikit. Selain itu letak sekolah dan daerah di Muara Enimtermasuk ke dalam lingkungan yang banyak sungai-sungai sehingga siswa sudah terbiasa dengan kegiatan di air.

\section{Faktor Eksternal}

Distribusi frekuensi penghambat belajar renang faktor eksternal disajikan dalam tabel berikut:

Tabel 6. Distribusi Frekuensi Hambatan Belajar Renang Faktor Eksternal.

\begin{tabular}{|c|c|c|c|c|}
\hline No. & Kategori & Interval & $\mathrm{F}$ & Persen \\
\hline 1 & Sangat Tinggi & $46,7925<X$ & 11 & $8,5 \%$ \\
\hline 2 & Tinggi & $39,9375<X \leq 46,7925$ & 28 & $21,5 \%$ \\
\hline 3 & Sedang & $33,0825<X \leq 39,9375$ & 44 & $33,8 \%$ \\
\hline 4 & Rendah & $26,2275<\mathrm{X} \leq 33,0825$ & 40 & $30,8 \%$ \\
\hline 5 & Sangat Rendah & $X \leq 26,2275$ & 7 & $5,4 \%$ \\
\hline \multicolumn{3}{|c|}{ Jumlah } & 130 & $100,0 \%$ \\
\hline
\end{tabular}

Dari tabel tersebut dapat diketahui bahwa 44 siswa $(33,8 \%)$ menyatakan ke dalam kategori "sedang”, 40 siswa (30,8\%) menyatakan ke dalam kategori "rendah", 28 siswa (21,5\%) menyatakan ke dalam kategori "tinggi", 11 siswa (8,5\%) menyatakan ke dalam kategori "sangat tinggi", dan 7 siswa $(5,4 \%)$ menyatakan ke dalam kategori "sangat rendah".Dari persentase tersebut dapat disimpulkan bahwa faktor eksternal termasuk ke dalam kategori hambatan "sedang".

Dari faktor eksternal penghambat belajar renang pada siswa kelas Xdi SMA Negeri 1 Muara Enim terdiri dari tiga indikator yaitulingkungan sosial, guru dan sarana prasarana. Adapun penjabarann dari masing-masing indikator yaitu

\section{Indikator Lingkungan Sosial}

Distribusi frekuensi penghambat belajar renang indikator lingkungan sosial disajikan dalam tabel berikut:

Tabel 7. Distribusi Frekuensi Hambatan Belajar Renang Indikator Lingkungan Sosial

\begin{tabular}{|c|c|c|c|c|}
\hline No. & Kategori & Interval & $\mathrm{F}$ & Persen \\
\hline 1 & Sangat Tinggi & $13,918<\mathrm{X}$ & 12 & $9,2 \%$ \\
\hline 2 & Tinggi & $11,246<X \leq 13,918$ & 8 & $6,2 \%$ \\
\hline 3 & Sedang & $8,574<X \leq 11,246$ & 79 & $60,8 \%$ \\
\hline 4 & Rendah & $5,902<\mathrm{X} \leq 8,574$ & 23 & $17,7 \%$ \\
\hline 5 & Sangat Rendah & $X \leq 5,902$ & 8 & $6,2 \%$ \\
\hline \multicolumn{3}{|c|}{ Jumlah } & 130 & $100,0 \%$ \\
\hline
\end{tabular}


Berdasarkan tabel di atas diketahui bahwa 79 siswa $(60,8 \%)$ menyatakan hambatan belajar renang indikator lingkungan sosial ke dalam kategori "sedang", 23 siswa (17,7\%) menyatakan ke dalam kategori "rendah", 12 siswa (9,2\%) menyatakan ke dalam kategori "sangat tinggi", 8 siswa $(6,2 \%)$ menyatakan ke dalam kategori "sangat tinggi" dan 8 siswa $(6,2 \%)$ menyatakan ke dalam kategori "sangat rendah". Dari persentase tersebut dapat disimpulkan bahwa faktor eksternal indikator lingkungan sosial termasuk ke dalam kategori hambatan "sedang".

Dari hasil penelitian disimpulkan bahwa indikator lingkungan sosial termasuk ke dalam kategori hambatan "sedang". Hal ini dikarenakan sebagian orang tua siswa di SMA Negeri 1 Muara Enim cenderung orang tua yang memiliki latar belakang perekonomian cukup baik, sehingga dalam mencukupi kebutuhan untuk belajar cenderung sudah baik. Selain itu SMA Negeri 1 Muara Enim juga termasuk ke dalam sekolah favoriteyang semua siswanya diseleksi dengan ketat dan termasuk siwasiswa terbaik. Sehingga sangat dimungkinkan orang tua siswa memberikan dukungan yang besar terhadap hasil belajar siswa.

\section{Indikator Guru}

Distribusi frekuensipenghambat belajar renang indikator guru dapat dilihat dalam tabel berikut ini:

Tabel 8. Distribusi Frekuensi Hambatan Belajar Renang Indikator Guru

\begin{tabular}{|c|c|c|c|c|}
\hline No. & Kategori & Interval & $\mathrm{F}$ & Persen \\
\hline 1 & Sangat Tinggi & $14,8855<X$ & 16 & $12,3 \%$ \\
\hline 2 & Tinggi & $11,246<X \leq 14,8855$ & 16 & $12,3 \%$ \\
\hline 3 & Sedang & $8,9315<X \leq 14,8855$ & 68 & $52,3 \%$ \\
\hline 4 & Rendah & $5,9545<X \leq 8,9315$ & 24 & $18,5 \%$ \\
\hline 5 & Sangat Rendah & $X \leq 5,9545$ & 6 & $4,6 \%$ \\
\hline \multicolumn{3}{|c|}{ Jumlah } & 130 & $100,0 \%$ \\
\hline
\end{tabular}

Berdasarkan tabel tersebut diketahui 68 siswa (52,3\%) menyatakan hambatan belajar renang indikator guru ke dalam kategori "sedang", 24 siswa (18,5\%) menyatakan ke dalam kategori "rendah", masing-masing 16 siswa (12,3\%) menyatakan ke dalam kategori "sangat tinggi" dan "tinggi", serta 6 siswa $(4,6 \%)$ menyatakan ke dalam kategori "sangat rendah".Dari persentase tersebut dapat 
disimpulkan bahwa faktor eksternal indikator guru termasuk ke dalam kategori hambatan "sedang".

Berdasarkan hasil penelitian disimpulkan bahwa indikator guru termasuk ke dalam kategori hambatan "sedang”. Hal ini dikarenakan guru di SMA Negeri 1 Muara Enim telah memiliki jam terbang yang cukup banyak untuk dapat menciptakan pembelajaran yang baik.

\section{Indikator Sarana dan Prasarana}

Distribusi frekuensi penghambat belajar renang indikator sarana dan prasarana dapat dilihat dalam tabel berikut ini:

Tabel 9. Distribusi Frekuensi Hambatan Belajar Renang Indikator Sarana dan

\section{Prasarana}

\begin{tabular}{|c|c|c|c|c|}
\hline No. & Kategori & Interval & $\mathrm{F}$ & Persen \\
\hline 1 & Sangat Tinggi & $21,1735<X$ & 8 & $6,2 \%$ \\
\hline 2 & Tinggi & $17,8445<X \leq 21,1735$ & 37 & $28,5 \%$ \\
\hline 3 & Sedang & $14,5155<X \leq 17,8445$ & 35 & $26,9 \%$ \\
\hline 4 & Rendah & $11,1865<X \leq 14,5155$ & 43 & $33,1 \%$ \\
\hline 5 & Sangat Rendah & $X \leq 11,1865$ & 7 & $5,4 \%$ \\
\hline \multicolumn{3}{|c|}{ Jumlah } & 130 & $100,0 \%$ \\
\hline
\end{tabular}

Berdasarkankan tabel tersebut diketahui 43 siswa $(33,1 \%)$ menyatakan hambatan indikator sarana dan prasarana ke dalam kategori "rendah", kemudian 37 siswa (28,5\%) menyatakan ke dalam kategori "tinggi", 35 siswa (26,9\%) menyatakan ke dalam kategori "sedang", 8 siswa $(6,2 \%)$ menyatakan ke dalam kategori "sangat tinggi" dan 7 siswa $(5,4 \%)$ menyatakan ke dalam kategori "sangat rendah".Dari persentase tersebut dapat disimpulkan bahwa faktor eksternal indikator sarana dan prasarana termasuk ke dalam kategori hambatan "rendah".

Dari hasil penelitian disimpulkan bahwa indikator sarana dan prasarana termasuk ke dalam kategori hambatan "rendah". Hal ini dikarenakan siswa dalam berenang sudah terbiasa tidak menggunakan kacamata renang, pakaian renag, dan pelindung rambut. Sehingga tidak adanya alat-alat tersebut tidak menjadi penghambat bagi siswa di SMA Negeri 1 Muara Enim. Selain itu siswa SMA Negeri 1 Muara Enim termasuk ke dalam siswa yang latar belakang perekonomian keluarga cukup baik sehingga siswa tidak measa keberatan dengan biaya kolam renang dan transportasi yang ditanggung secara pribadi. 


\section{SIMPULAN}

Berdasarkan hasil penelitian, dapat disimpulkan bahwa hambatan belajar renang pada siswa kelas Xdi SMA Negeri 1 Muara Enim pada faktor internal termasuk kedalam kategori hambatan "sedang" dan faktor eksternal termasuk ke dalam kategori hambatan "sedang". Pada faktor internal indikator fisiologis termasuk kedalam kategori "rendah", indikator psikologis termasuk ke dalam kategori "sedang". Pada faktor eksternal indikator lingkungan social termasuk ke dalam kategori "sedang", guru termasuk kedalam kategori hambatan "sedang" dan sarana dan prasarana masuk kedalam kategori "rendah".

\section{SARAN}

1. Bagi siswa, agar siswa lebih bersemangat dan bersungguh-sungguhdalam mengikuti pembelajaran pendidikan jasmani pada umumnya dan pembelajaran renang pada khususnya.

2. Bagi guru, diharapkan dapat menambah pengetahuan dan keterampilan yang berhubungan dengan renang baik teori maupun praktek, serta dapat menciptakan pembelajaran renang yang kreatif dan inovatif sehingga siswa dapat mengikuti pembelajaran dengan baik.

3. Bagi penelitian selanjutnya, sebaiknya butir-butir instrument untuk uji coba diperbanyak, sehingga kemungkinan tidak valid dapat diminimalisir.

\section{DAFTAR PUSTAKA}

(2002). Kamus Besar Bahasa Indonesia. Jakarta: Balai Pustaka

Aunurrahman. (2009). Belajar dan Pembelajaran. Bandung: Alfabeta

Bambang Sardjono. (2010). Skripsi: Kreativitas Guru Penjasorkes dalam Memodifikasi Sarana dan Prasarana Pembelajaran di SD se Kecamatan Poncowarno Kabupaten Kebumen. Yogyakarta: FIK UNY.

Cholid Narbuko \& Abu Achmadi. (2007). Metodologi Penelitian. Jakarta: PT Bumi Angkasa.

Emat Suryatna \& Adang Suherman. (2004). Renang kompetitif: Alternatif untuk SLTP. Jakarta: Direktorat jenderal Olahraga Depdiknas Miyanto. (2008). Ayo Berenang. Yogyakarta: CV Empat Pilar Pendidikan. 
Volume 4 Nomor 2, Oktober 2018

Sardiman A.M.. (2010). Interaksi dan Motivasi Belajar-mengajar. Jakarta: Rajawali Pers.

Slameto. (2010). Belajar Dan Faktor-Faktor Yang Mempengaruhi. Jakarta: Rineka Cipta.

Sugihartono. (2009). Psikologi Pendidikan. Yogyakarta: UNY Press

Supriyadi. (2013). Strategi Belajar dan Mengajar. Yogyakarta: Jaya Ilmu.

Sugiyono. (2010). Metode Penelitian Pedidikan (Pendekatan Kuantitatif, Kualitatif dan $R \& D)$ ). Bandung: Alfabeta.

Sutrisno Hadi. (1991). Analisis butir-Butir Instrumen Penelitian. Yogyakarta: Andi Offset. 